\title{
EVALUASI PENERAPAN ZONA SELAMAT SEKOLAH DI KOTA PADANG
}

\author{
Titi Kurniati ${ }^{1}$, Hendra Gunawan ${ }^{2}$, Dony Zulputra ${ }^{3}$
}

\begin{abstract}
ABSTRAK
Pembangunan di bidang angkutan jalan saat ini mengutamakan peningkatan keselamatan dan penertiban lalu lintas dan angkutan jalan, dengan sasaran menurunkan angka kecelakaan lalu lintas, baik yang dipengaruhi oleh faktor teknik (sarana dan prasarana) maupun oleh pemakai jalan (pengemudi dan pejalan kaki). Seperti program Zona Selamat Sekolah (ZoSS) yang diterapkan di Kota Padang, bertujuan untuk meningkatkan keselamatan dan kenyamanan pejalan kaki (khusus siswa sekolah) dalam menyeberangi jalan.

Penelitian ini bertujuan untuk mengevaluasi pelaksanaan ZoSS dimana untuk kota Padang diberlakukan tanpa ada uji coba program atau studi awal. Metode yang digunakan mengacu pada Peraturan No.: SK 3236/AJ 403/DRJD/2006 tentang UJI COBA PENERAPAN ZONA SELAMAT SEKOLAH. Analisa data dilakukan dengan statistik distribusi normal (uji Z), dengan membandingkan nilai Zhitung dengan nilai Ztabel dengan tingkat kesalahan 5\% untuk perilaku penyeberang, perilaku pengantar dan kecepatan kendaraan.

Hasil studi menunjukkan bahwa setelah diterapkan ZoSS, siswa sekolah belum selamat, kecuali dibantu petugas polisi. Sehingga disimpulkan penerapan ZoSS di Kota Padang belum memenuhi sasaran perencanaan.
\end{abstract}

Kata Kunci : Zona Selamat Sekolah, distribusi normal.

\section{PENDAHULUAN}

\subsection{Latar Belakang}

Berjalan kaki adalah bagian dari pergerakan pelaku perjalanan dan merupakan sarana transportasi yang paling sederhana, tetapi berada posisi yang lemah dan rentan terhadap konflik atau kecelakaan saat mereka bercampur dengan moda transportasi yang lain. Anak sekolah usia dibawah 14 tahun seringkali belum mengerti dengan aturan berlalu lintas, karena dalam pendidikan dasar kita tidak diajarkan tata cara berlalu lintas sebagai pejalan kaki. Sehingga tabrakan antara kendaraan dan pejalan kaki sering tidak dapat dihindarkan yang berakibat luka-luka atau kematian.

Pelaksanaan Zona Selamat Sekolah (ZoSS) merupakan salah satu bentuk manajemen lalu lintas dalam rangka pemenuhan rasa aman dalam menyeberang jalan bagi pejalan kaki. Penerapannya adalah pada ruas jalan di area sekolah yang memiliki lalu lintas pejalan kaki anak sekolah cukup tinggi dan rentan kecelakaan lalu lintas.

\footnotetext{
${ }^{1}$ Staf Pengajar Jurusan Teknik Sipil Fakultas Teknik Universitas Andalas, e-mail: titi@ft.unand.ac.id

${ }^{2}$ Staf Pengajar Jurusan Teknik Sipil Fakultas Teknik Universitas Andalas, e-mail: hendra@ft.unand.ac.id

${ }^{3}$ Mahasiswa Jurusan Teknik Sipil Fakultas Teknik Universitas Andalas
} 


\subsection{Tujuan Penelitian}

Adapun tujuan dari penelitian ini adalah :

1. Mengidentifikasi ruas jalan di Kota Padang dimana perlu diterapkan Zona Selamat Sekolah (ZoSS).

2. Melakukan evaluasi terhadap penerapan Zona Selamat Sekolah (ZoSS) yang telah dipasang di Kota Padang.

Manfaat dari penelitian ini adalah berupa rekomendasi kepada pihak terkait (Pemko dan Dinas Perhubungan) Kota Padang mengenai hasil penilaian terhadap evaluasi digunakan sebagai bahan perbaikan bila ternyata program ini belum dilaksanakan dengan baik.

\subsection{Batasan Masalah}

Batasan masalah dari penelitian ini adalah :

1. Evaluasi mengambil sampel 3 (tiga) lokasi ZoSS, yaitu SMP N 31 Padang, SD N 03 Alai dan SD N 04-21 Purus.

\section{DASAR TEORI}

\subsection{Zona Selamat Sekolah (ZoSS)}

Zona Selamat Sekolah (ZoSS) adalah lokasi di ruas jalan tertentu yang merupakan zona kecepatan berbasis waktu untuk mengatur kecepatan kendaraan di lingkungan sekolah.

Tipe Zona Selamat Sekolah (ZoSS) ditentukan berdasarkan tipe jalan, jumlah lajur, kecepatan rencana jalan dan jarak pandangan henti yang diperlukan. Berdasarkan tipe ZoSS dapat ditentukan batas kecepatan ZoSS, panjang ZoSS dan perlengkapan jalan yang dibutuhkan. Tabel 1. menampilkan kebutuhan perlengkapan jalan berdasarkan tipe (ZoSS).

Tabel 1. Kebutuhan Perlengkapan Jalan Berdasarkan ZoSS

\begin{tabular}{|c|c|c|c|c|c|c|c|}
\hline Tipe Jalan & $\begin{array}{c}\text { Jarak } \\
\text { Pandangan } \\
\text { Henti (meter) }\end{array}$ & $\begin{array}{l}\text { Batas } \\
\text { Kecepatan } \\
\text { Rencana } \\
(\mathrm{km} / \mathrm{jam})\end{array}$ & $\begin{array}{c}\text { Batas Kecepatan } \\
\text { Zona Selamat } \\
\text { Sekolah } \\
(\mathrm{km} / \mathrm{jam})\end{array}$ & Tipe ZoSS & $\begin{array}{c}\text { Panjang ZoSS } \\
\text { (meter) }\end{array}$ & Kebutuhan Minimum & Kebutuhan Tambahan \\
\hline \multirow{2}{*}{$\begin{array}{l}2 \text { lajur } \\
\text { Tak } \\
\text { Terbagi } \\
(2 / 2 \text { UD) }\end{array}$} & $50-85$ & $>40, \leq 60$ & 25 & 2UD-25 & 150 & $\begin{array}{l}\text { marka ZoSS, zebra cross, rambu-rambu } \\
\text { lalu lintas,marka jalan zigzag wama } \\
\text { kuning, pemandu penyeberang. }\end{array}$ & $\begin{array}{l}\text { pita penggaduh, APILL pelikan, } \\
\text { APILL berkedip }\end{array}$ \\
\hline & $35-50$ & $30-40$ & 20 & 2 UD-20 & 80 & $\begin{array}{l}\text { marka ZoSS, zebra cross, rambu-rambu } \\
\text { lalu lintas,pemandu penyeberang. }\end{array}$ & $\begin{array}{l}\text { marka jalan zigzag warna kuning, pita } \\
\text { penggaduh, APILL pelikan }\end{array}$ \\
\hline \multirow{2}{*}{$\begin{array}{l}\text { 4 lajur } \\
\text { Tak } \\
\text { Terbagi } \\
\text { (4/2UD) }\end{array}$} & $50-85$ & $>40, \leq 60$ & 25 & 4UD-25 & 150 & $\begin{array}{l}\text { marka ZoSS, zebra cross, rambu-rambu } \\
\text { lalu lintas,marka jalan zigzag wama } \\
\text { kuning, pita penggaduh, pemandu } \\
\text { penyeberang. }\end{array}$ & APILL pelkan, APILL berkedip \\
\hline & $35-50$ & $30-40$ & 20 & 4UD-20 & 80 & $\begin{array}{l}\text { marka ZoSS, zebra cross, rambu-rambu } \\
\text { lalu lintas,marka jalan zigzag wama } \\
\text { kuning, pemandu penyeberang. }\end{array}$ & $\begin{array}{l}\text { pita penggaduh, APILL pelikan, } \\
\text { APILL berkedip }\end{array}$ \\
\hline \multirow{2}{*}{$\begin{array}{l}4 \text { lajur } \\
\text { Terbagi } \\
(4 / 2 \mathrm{D})\end{array}$} & $50-85$ & $>40, \leq 60$ & 25 & $4 \mathrm{D}-25$ & 200 & $\begin{array}{l}\text { marka ZoSS, zebra cross, rambu-rambu } \\
\text { lalu lintas, marka jalan zigzag wama } \\
\text { kuning, pita penggaduh, APILI pelikan, } \\
\text { pemandu penyeberang. }\end{array}$ & APILL berkedip \\
\hline & $35-50$ & $30-40$ & 20 & $4 \mathrm{D}-20$ & 100 & $\begin{array}{l}\text { marka ZoSS, zebra cross, rambu-rambu } \\
\text { lalu lintas, marka jalan zigzag wama } \\
\text { kuning, pita penggaduh, pemandu } \\
\text { penyeberang. }\end{array}$ & APILL pelikan, APILL berkedip \\
\hline \multicolumn{3}{|c|}{$>4$ lajur dan/atau kecepatan $>60 \mathrm{~km} / \mathrm{jam}$} & \multicolumn{5}{|c|}{ u penyeberangan tidak sebidang } \\
\hline
\end{tabular}

(Sumber : Peraturan DirJen Hub.Dat No: 3236/AJ 403/DRJD/2006) 
Waktu operasi Zona Selamat Sekolah direkomendasikan 2 jam di pagi hari dan 2 jam di siang hari, antara pukul 6.30-8.30 pagi dan 12.00-14.00 di siang hari pada hari sekolah atau dilaksanakan selama jam sekolah berlangsung, kecuali hari libur. Waktu operasi ini dapat disesuaikan dengan kebutuhan masing-masing sekolah.

\subsection{Fasilitas Perlengkapan Jalan pada Zona Selamat Sekolah}

\subsubsection{Marka Jalan}

a. ZONA SELAMAT SEKOLAH adalah marka berupa kata-kata sebagai pelengkap rambu batas kecepatan Zona Selamat Sekolah, seperti terlihat pada Gambar 1.

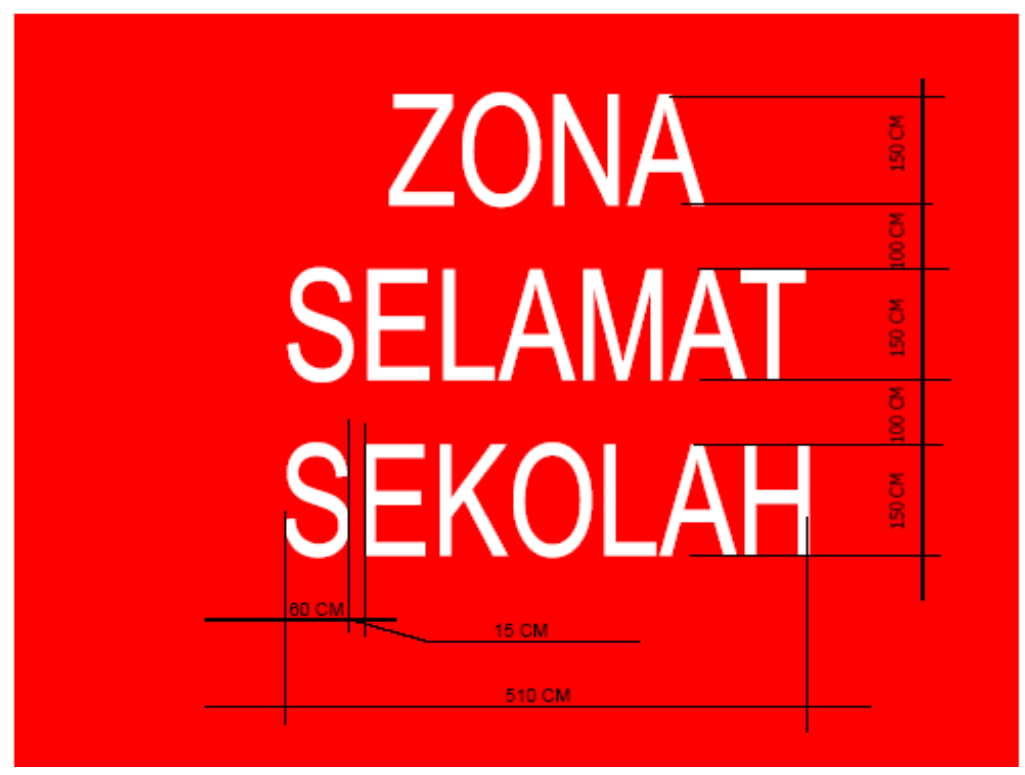

Gambar 1. Marka Zona Selamat Sekolah

b. TENGOK KANAN-KIRI, adalah marka berupa kata-kata pada tepi zebra cross. Marka ini dimaksudkan agar penyeberang khususnya penyeberang anak-anak memperhatikan arah datangnya kendaraan sebelum menyeberang (Gambar 2).



Gambar 2. Marka Tengok Kanan dan Kiri

c. Tanda Permukaan Jalan Larangan Parkir (marka zig zag warna kuning) yang dipasang sepanjang ZoSS (Gambar 3). 


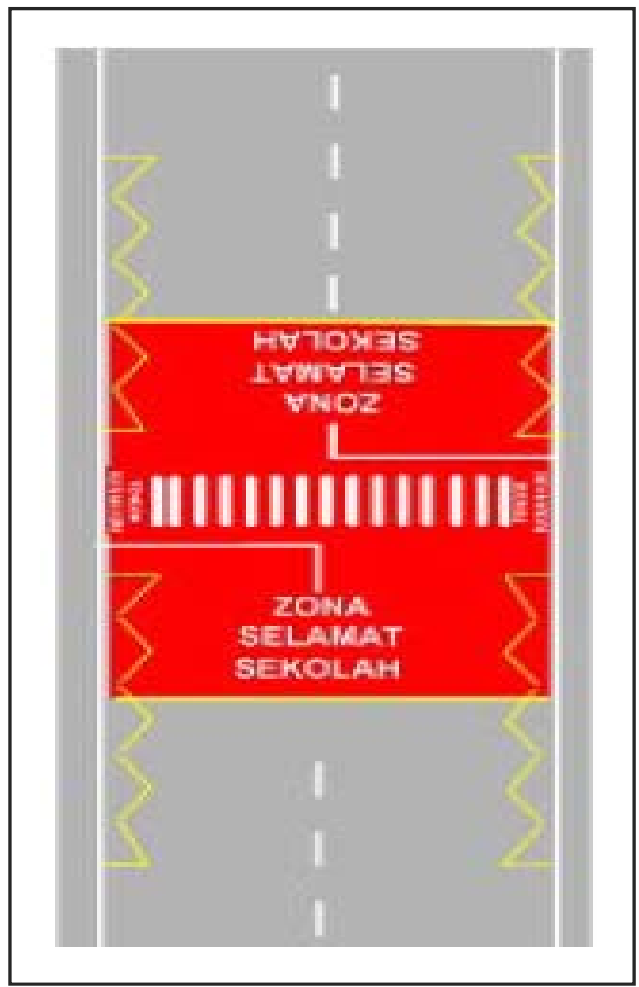

Gambar 3. Marka Jalan Pada ZoSS

d. Pita Penggaduh

Pita penggaduh dapat dipasang untuk meningkatkan kewaspadaan. Sesuai Lampiran 7 KM 3 Tahun 1994 tentang Alat Pengendali dan Pengaman Pemakai Jalan, pita penggaduh dipasang pada jarak 50 meter dari awal ZoSS dengan ketinggian 1 (satu) centimeter (Gambar 4).

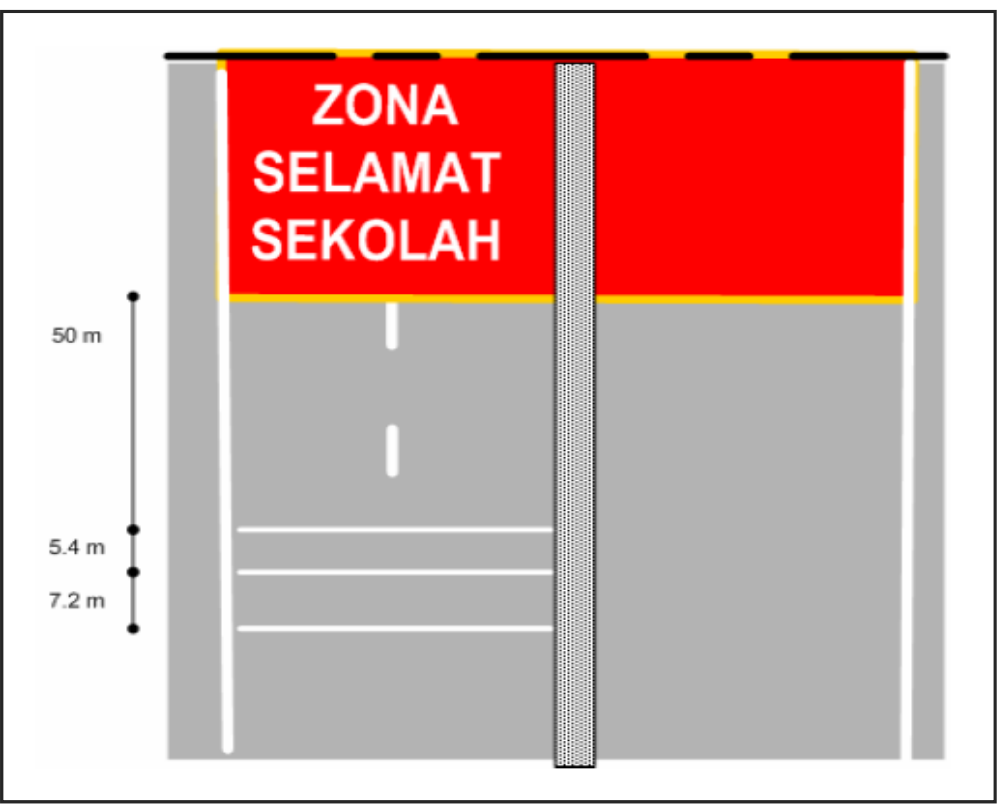

Gambar 4. Pita Pengggaduh 


\subsubsection{Rambu-rambu Lalu Lintas}

Rambu-rambu lalu lintas (selanjutnya disebut rambu) yang digunakan pada Zona Selamat Sekolah adalah :

1. Rambu peringatan hati-hati.

2. Papan peringatan berupa kata-kata KURANGI KECEPATAN ZONA SELAMAT SEKOLAH.

3. Rambu peringatan penyeberangan orang.

4. Rambu peringatan lampu pengatur lalu lintas.

5. Rambu batas kecepatan maksimum dengan papan tambahan informasi perioda batasan kecepatan.

6. Rambu larangan parkir sepanjang Zona Selamat Sekolah.

7. Rambu petunjuk tempat penyeberangan jalan.

8. Rambu batas akhir kecepatan maksimum.

\subsubsection{Contoh Tipikal ZoSS}

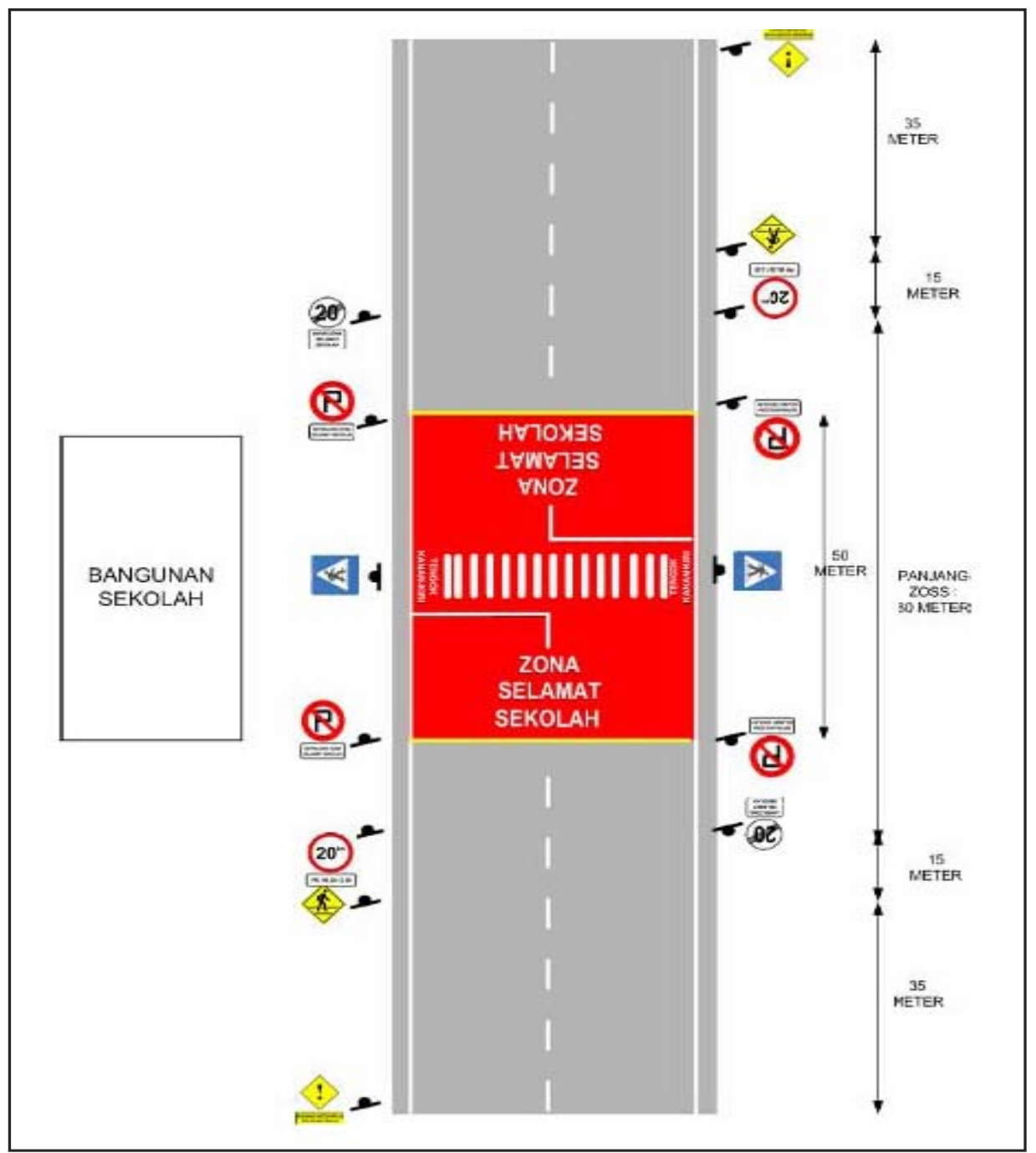

Gambar 5. ZoSS pada Tipe Jalan 2/2 UD 


\subsubsection{Prosedur Penyelenggaraan ZoSS}

Prosedur penyelenggaraan ZoSS disajikan pada bagan alir berikut.

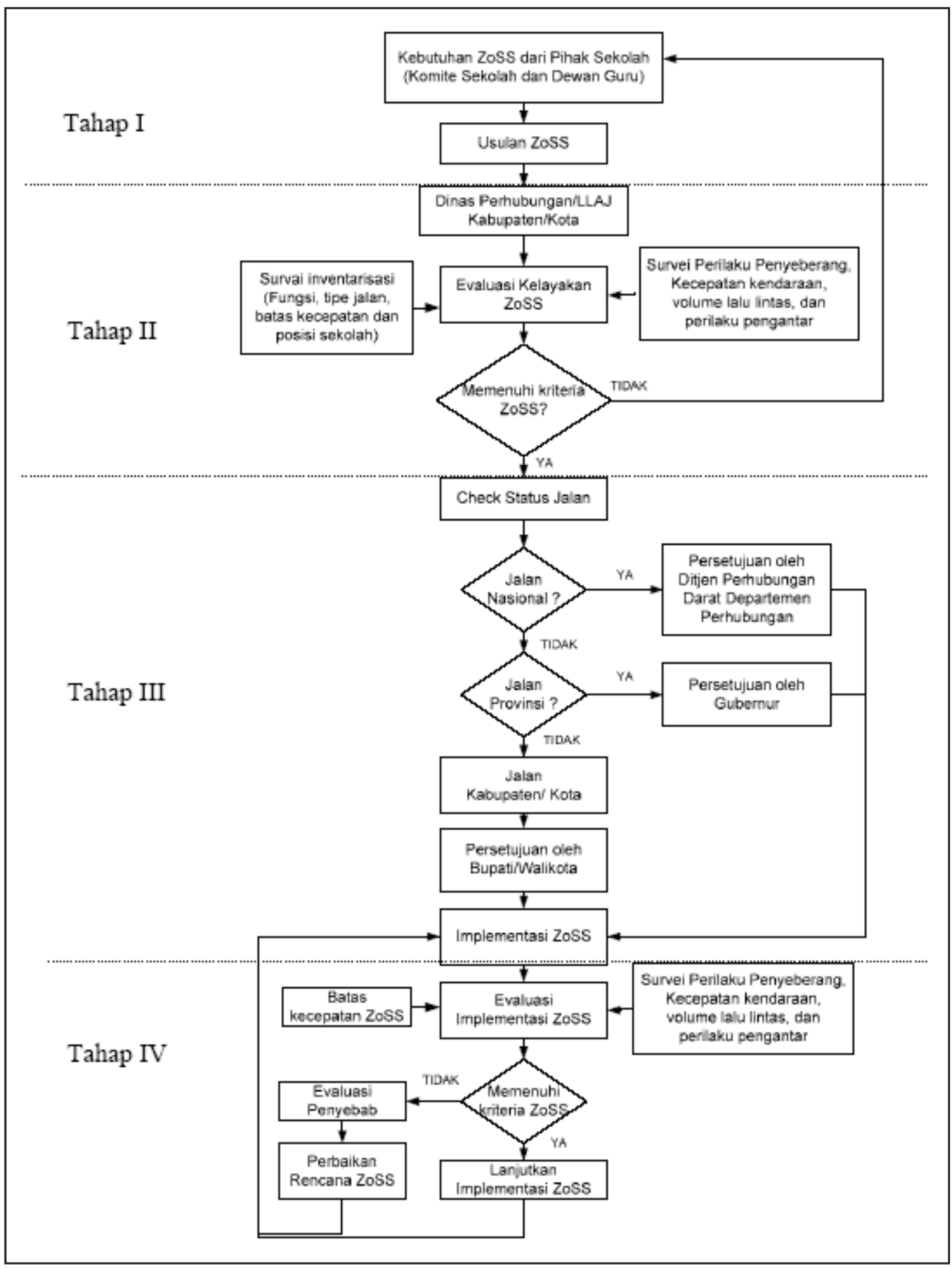

Gambar 6. Bagan Alir Prosedur Penyelenggaraan ZoSS 


\subsection{Survei Evaluasi Penerapan ZoSS}

1. Pengukuran dimensi jalan dan ZoSS serta pendataan semua perlengkapan fasilitas Zona Selamat Sekolah.

2. Survei perilaku penyeberang jalan.

a. Populasi dari survai ini adalah semua siswa yang berada di sekolah tersebut, mereka beraktifitas menyeberang jalan hampir tiap hari.

b. Ukuran sample adalah minimal $10 \%$ dari jumlah siswa di sekolah tersebut. Metode pemilihan sampel adalah acak sederhana (simple random sampling), dengan waktu pengambilan disesuaikan waktu belajar di sekolah bersangkutan. Ada 4 (empat) kriteria yang dinilai terhadap perilaku siswa menyeberang jalan, yaitu :

- Prosedur baku cara menyeberang.

- Cara menyeberang (berjalan atau berlari).

- Fasilitas yang digunakan dalam menyeberang.

- Status penyeberang (mandiri atau tidak mandiri).

c. Analisa data dengan menggunakan statistik uji normal, yaitu :

$$
\text { Zhit }=\frac{\bar{P}-0,5}{\sqrt{\frac{\bar{P}(1-\bar{P})}{n}}} \quad ; \quad P=\frac{\sum \text { kelompok }}{n}
$$

dimana $n$ adalah ukuran sampel.

d. Kesimpulan, jika nilai Zhit dibandingkan dengan Ztabel, maka:

- Zhit $\geq$ Ztabel Perilaku pejalan kaki di sekolah tersebut sudah selamat dengan tingkat kesalahan 5\%.

- Zhit $<$ Ztabel Perilaku pejalan kaki di sekolah . tersebut belum selamat dengan tingkat kesalahan $5 \%$.

3. Survei kecepatan dan volume lalu lintas.

a. Kecepatan sesaat kendaraan melewati ZoSS diukur dengan alat speed gun.

- Populasi dalam survai ini adalah semua kendaraan yang lewat di jalan sekolah.

- Ukuran sample adalah minimal 30 unit kendaraan. Metode pemilihan sample adalah dengan acak sederhana (simple random sampling). Analisa data, dengan menggunakan statistik uji Z, dimana :

$$
\text { Zhit }=\frac{\bar{X}-20}{\frac{S d}{\sqrt{n}}} \quad ; \quad X=\frac{\sum X_{i}}{n} \quad ; \quad S d=\sqrt{\frac{\sum\left(X_{i}-\bar{X}\right)^{2}}{n-1}}
$$

- Kesimpulan, jika nilai Zhit dibandingkan dengan Ztabel, maka:

- Zhit $\leq$ Ztabel maka jalan di sekolah tersebut sudah selamat dengan tingkat kesalahan $5 \%$.

- Zhit $>$ Ztabel maka jalan di sekolah tersebut belum selamat dengan tingkat kesalahan 5\%.

b. Volume kendaraan

- Populasi dalam survai adalah semua kendaraan yang lewat di jalan sekolah.

- Kendaraan disurvai, diklasifikasikan kedalam 4 kelompok, yaitu : Kendaraan ringan (LV), Kendaraan Berat (HV), Sepeda motor (MC), Kendaraan tidak bermotor.

- Kesimpulan, dengan diperolehnya nilai rasio volume $(Q)$ per kapasitas $(C)$ dan tingkat pelayanan akan terlihat perilaku lalu lintas.

4. Survei perilaku pengantar siswa.

- Populasi merupakan jumlah kendaraan pengantar siswa baik kedaraan pribadi ataupun bus sekolah atau angkutan umum 
- Ukuran sampel minimal adalah 10\% dari jumlah siswa sekolah tersebut Metode pemilihan sampel adalah dengan acak sederhana (simple random sampling).

- Analisa data sama dengan analisa data perilaku penyeberang jalan.

\section{ANALISA DAN PEMBAHASAN}

\subsection{Waktu Pelayanan ZoSS}

Sebagai sebuah zona yang ditujukan untuk meningkatkan keselamatan pejalan kaki, ZoSS didepan sekolah lokasi penelitian (SMP N 31 Padang, SD N 03 Alai, SD N 04-21 Purus) sudah dilengkapi dengan alat pengendali lalu lintas (marka dan rambu lalu lintas)

Pembatasan kecepatan berbasis waktu dilakukan untuk periode waktu jam 06.30 sampai jam 13.00, dimana pada siswa mulai datang ke lokasi dan meninggalkan lokasi pada periode tersebut. Tapi dilapangan ditemukan bahwa periode kedatangan dan kepergian melewati waktu tersebut, kecuali pada SD N 03 Alai Padang. Pada SMP N 31 Padang, siswa mulai datang jam 06.45 dan meninggalkan lokasi sekolah pada jam 14.30 karena jam pulang sekolah adalah jam 14.15. Sementara di SD N 04-21, siswa mulai datang jam 06.50 dan meninggalkan lokasi sekolah pada jam 17.00 karena adanya sistem dua shift, yaitu shift I untuk SD N 13 dan SD N 14 pada pagi hari (07.30 - 12.15) dan shift II untuk SD N 04 dan SD N 21 pada siang hari (12.30-15.00).

Sesuai dengan Peraturan Direktur Jenderal Perhubungan Darat nomor SK 3236/AJ 403/DRJD/2006 mengenai waktu operasi ZoSS yang direkomendasikan 2 jam di pagi hari (06.30-08.30) dan 2 jam di siang hari (12.00-14.00) dapat disesuaikan dengan kebutuhan sekolah. Oleh karena itu perlu adanya penyesuaian waktu operasi ZoSS di Kota Padang sesuai dengan kedatangan dan kepulangan siswa sekolah masing-masing, agar penerapan program ZoSS dapat memenuhi sasaran perencanaan.

\subsection{Perilaku Penyeberang Jalan dan Pengantar}

Perilaku siswa dalam menyeberang di uji dengan statistik distribusi normal (uji Z) terlihat pada Tabel 2, dan perilaku pengantar ditampilkan pada Tabel 3.

Tabel 2. Uji Perilaku Penyeberang Jalan

\begin{tabular}{|l|c|c|c|c|c|c|}
\hline \multirow{2}{*}{ Lokasi ZoSS } & \multicolumn{2}{|c|}{$\boldsymbol{P}$} & \multicolumn{2}{c|}{ Zhitung } & \multirow{2}{*}{ Ztabel } & \multirow{2}{*}{ Keterangan } \\
\cline { 2 - 5 } & Pagi & Siang & Pagi & Siang & & Jika Zhit $\geq$ Ztabel, \\
maka penyeberang \\
Sudah N 31 Padang & 0.59 & 0.58 & 1.792 & 1.613 & \multirow{2}{*}{1.645} \\
\hline SD N 03 Alai & 0.65 & 0.58 & 2.388 & 1.384 & & \\
\hline SD N 04-21 Purus & 0.62 & 0.58 & 1.588 & 1.426 & & \\
\hline
\end{tabular}

Tabel 3. Uji Perilaku Pengantar

\begin{tabular}{|c|c|c|c|c|c|c|}
\hline \multirow{2}{*}{ Lokasi ZoSS } & \multicolumn{2}{|c|}{$\boldsymbol{P}$} & \multicolumn{2}{|c|}{ Zhitung } & \multirow{2}{*}{ Ztabel } & \multirow{2}{*}{ Keterangan } \\
\hline & Pagi & Siang & Pagi & Siang & & \\
\hline SMP N 31 Padang & 0.60 & 0.59 & 1.707 & 1.453 & \multirow{3}{*}{1.645} & \multirow{3}{*}{$\begin{array}{l}\text { Jika Zhit } \geq \text { Ztabel, } \\
\text { maka penyeberang } \\
\text { sudah selamat }\end{array}$} \\
\hline SD N 03 Alai & 0.62 & 0.60 & 2.019 & 1.881 & & \\
\hline SD N 04-21 Purus & 0.54 & 0.59 & 0.567 & 1.569 & & \\
\hline
\end{tabular}


Perilaku siswa dalam menyeberang jalan pada SMPN 31 dan SDN 03 Alai di pagi hari sudah selamat, hal ini dimungkinkan dengan adanya petugas polisi yang membantu. Sedangkan pada SDN 04-21 Purus tanpa bantuan petugas di pagi hari siswa belum selamat, seperti juga pada siang hari. Hal ini demikian juga terjadi pada perilaku pengantar.

\subsection{Analisa Kecepatan Kendaraan}

Analisa kecepatan kendaraan terhadap keselamatan siswa dalam menyeberang di uji dengan statistik distribusi normal (uji Z), dapat dilihat pada Tabel 4. Hasil analisa Uji Z dengan tingkat kesalahan $5 \%$.

Tabel 4. Uji Z Kecepatan Kendaraan

\begin{tabular}{|c|c|c|c|c|c|c|}
\hline \multirow{2}{*}{ Lokasi } & \multirow{2}{*}{ Lajur Menuju } & \multicolumn{2}{|c|}{ Standar Deviasi } & \multicolumn{2}{|c|}{ Zhitung } & \multirow{2}{*}{ Ztabel } \\
\hline & & Pagi & Siang & Pagi & Siang & \\
\hline \multirow{2}{*}{ SMP N 31 Padang } & Unand & 4.189 & 5.246 & 0.774 & 2.827 & \multirow{6}{*}{1.645} \\
\hline & Pasar Raya & 4.992 & 5.609 & 1.358 & 2.619 & \\
\hline \multirow{2}{*}{ SD N 03 Alai } & Jati & 4.154 & 4.312 & 0.354 & 1.808 & \\
\hline & Gunung Pangilun & 5.078 & 4.086 & 1.478 & 3.248 & \\
\hline \multirow{2}{*}{ SD N 04-21 Purus } & Ulak Karang & 3.877 & 4.86 & 5.694 & 6.591 & \\
\hline & Pasar Raya & 3.944 & 4.972 & 6.362 & 7.758 & \\
\hline
\end{tabular}

(Sumber : Hasil analisa kecepatan kendaraan)

Kecepatan kendaraan pada lokasi ZoSS pagi hari terlihat pada lokasi SMPN 31, SDN 03 Alai Zhit lebih kecil dari Ztabel, maka penyeberang dikatakan sudah selamat, hal ini sangat dimungkinkan dengan adanya bantuan petugas polisi dalam mengatur lalu lintas. Sedangkan pada SDN 04-21 Purus Zhit lebih besar dari Ztabel, maka penyeberang dikatakan belum selamat. Begitu pula kondisi pada siang hari pada semua lokasi karena Zhit lebih besar dari Ztabel maka penyeberang dikatakan belum selamat. Jadi terlihat bahwa keberadaan ZoSS belum dipahami oleh pengguna jalan.

Untuk perilaku lalu lintas dapat dianalisis dari $V / C$ yang terlihat pada Tabel 5.

Tabel 5. Analisa V/C Ruas Jalan

\begin{tabular}{|l|c|c|c|c|}
\hline \multicolumn{1}{|c|}{ Lokasi } & $\begin{array}{c}\text { Total Kendaraan } \\
\text { (smp/jam) }\end{array}$ & $\begin{array}{c}\text { Kapasitas Jalan } \\
\text { (smp/jam) }\end{array}$ & $\boldsymbol{Q} / \boldsymbol{C}$ & $\begin{array}{c}\text { Tingkat Layanan } \\
\text { (LOS) }\end{array}$ \\
\hline SMP N 31 Padang & 2143.88 & 3609 & 0.59 & $\mathrm{~B}$ \\
\hline SD N 03 Alai & 2197.91 & 3890.64 & 0.56 & $\mathrm{~B}$ \\
\hline SD N 04-21 Purus & 2224.96 & 6937.63 & 0.32 & $\mathrm{~B}$ \\
\hline
\end{tabular}

Berdasarkan derajat kejenuhan atau rasio $\mathrm{Q} / \mathrm{C}$ dan tingkat pelayanan (LoS) pada ruas jalan di lokasi survei terlihat rasio $\mathrm{Q} / \mathrm{C}$ adalah berkisar $0,32-0.59$ dengan tingkat layanan $\mathrm{B}$. Hal ini menunjukkan bahwa arus stabil dengan dengan volume lalu lintas sedang dan kecepatan mulai dibatasi oleh kondisi lalu lintas. 


\section{KESIMPULAN}

Berdasarkan hasil analisis yang telah dilakukan, dapat diambil kesimpulan sebagai berikut :

1. Program ZoSS di Kota Padang belum berjalan sesuai rencana. Hal ini terlihat dari uji perilaku penyebrang jalan dan pengantar, serta uji kecepatan kendaraan pada lokasi penelitian menunjukkan siswa sekolah belum selamat walaupun ada ZoSS, kecuali ada bantuan petugas polisi.

2. Disarankan untuk peningkatan kepatuhan pengguna jalan dan siswa melalui peningkatan sosialisasi tentang ZoSS dan manfaatnya (berupa leaflet, sosialisasi lewat media cetak dan elektronik, ceramah ke sekolah, lomba keselamatan dan lain-lain).

\section{DAFTAR PUSTAKA}

Departemen Perhubungan Direktur Jenderal Perhubungan Darat, (2006), "Uji Coba Penerapan Zona Selamat Sekolah di 11 (Sebelas) Kota di Pulau Jawa”, Peraturan No.: SK 3236/AJ 403/DRJD/2006.

Lembaga Pengabdian Pada Masyarakat ITB, (1997), "Metode Survei Lalu lintas dan Transportasi”, KBK Rekayasa Transportasi Jurusan Teknik Sipil, ITB. 